\title{
Henriette Jæger and Jan Ketil Torgersen (red.): Medialisert barndom: digital kultur i barnhagen. Oslo: Universitetsforlaget. 2012.
}

\author{
Lotte Nyboe
}

MedieKultur 2013, 54, 197-199

Published by SMID | Society of Media researchers In Denmark | www.smid.dk The online version of this text can be found open access at www.mediekultur.dk

Antologien Medialisert barndom: digital kultur i barnehagen falder på et tørt sted, for endnu er der ikke skrevet mange bøger om et ellers højaktuelt emne - digitalisering af børnehaven. Bogen sætter fokus på børnehaven som digital dannelsesarena samt hvilke krav, de digitale medier stiller til de voksne. Og selvom empirien fortrinsvis er norsk og de fleste forfattere nordmænd, er bogens diskussioner meget relevante i forhold til en dansk børnehavekontekst. Bogen indledes af Ivar Selmer-Olsen, der i et tilbageblik funderer over børneliv og medier. Tonen slås an - de gamle medier eller spil (fx Ludo) er ikke nødvendigvis mere udviklende end computerspil, for digitale medier er værktøjer og kan skabe både godt og skidt afhængigt af, hvad de bruges til. Den voksnes rolle er, som Selmer-Olsen skriver, at "hjelpe barn til å ta kontroll og til å skille mellom skitt og kanel" (p. 19).

Antologien består af ni kapitler, der på hver deres måde tilgår emnet. I det første kapitel, "Den medialiserede leg", sætter Stine Liv Johansen fokus på sammenhængen mellem leg og medier. Med gode introduktioner til begreberne medialisering og legekultur skabes en ramme inden for hvilken læsere bringes til at forstå, at medierne skal tages alvorligt som et nutidigt omdrejningspunkt for børns leg. Det er ikke et spørgsmål om enten-eller, for børn skal fortsat stimuleres til eksempelvis fysisk aktivitet. I andet kapitel, "Vår digital musikkverden", redegør Jan Ketil Torgersen for udviklingen af musikteknologien og problematiserer digitale mediers indflydelse på børns musiske udtryksmåder. I modsætning til det foregående kapitel udtrykkes der en vis skepsis over for de digitale medier, for eksempel når forfatterende næsten lidt polemisk spørger: "Betyr det at vi må si ja til alt? 
Eller kan barnhagen også representere en motkultur til all den påvirkning vi uansett bliver utsatt for?" (p. 48). Derved føler man sig hensat til datidens effektforskning og dennes resultater angående mediernes skadelige påvirkning. I tredje kapitel, "Barna som robuste og empatiske IKT-aktører", diskuterer Svein Sando digital dannelse og hvad børnehaven kan gøre for at igangsætte og skabe en digital dannelsesproces. Dannelse kræver tid, ikke mindst den digitale dannelse, der skal klæde børn på til at kunne begå sig etisk og sikkert i den digitale verden. Læseren bringes tæt på børnehaven og får egentlige eksempler på, hvorledes digitale medier kan indgå i dagligdagens aktiviteter. I fjerde kapitel, "Skal vi ta på eventyr eller tegne", viser Margareth Sandvik, hvorledes interaktive tavler og læsebræt kan anvendes i flersprogede børnegrupper i børnehaven. Herigennem får flersprogede børn mulighed for at udvikle både deres modersmål og andetsprog i børnehaven. Kapitlet er læsevenligt og interessant ikke mindst på grund af flere gode eksempler på sociale interaktioner mellem børnene og den professionelle. I femte kapitel, "Nye digitale begivenheder - nye former for deltakelse i Fløyensfugl barnehage", tager Elin Eriksen Ødegaard og Ida Magrethe Knudsen afsæt i projektet "Barnhagen som danningsarena" og diskuterer digital pædagogik. Med afsæt $\mathrm{i}$ et både interessant og solidt teoriapparat konkluderer forfatterne, at en ny, digital billedpædagogisk praksis kræver deltagende voksne, der involverer sig ikke kun i det, der sker på skærmene, men også bag dem. Forfatterne introducerer begrebet deltagende handlingsrum, hvori børn og voksne 'samhandler' omkring den visuelle begivenhed. De voksne medvirker ved for eksempel at komme med indspil til skabelsesprocessen og stille spørgsmål, der kan hjæelpe børnene videre, hvis de er gået i stå. I det sjette kapitel, "Bruk av dataspill i norske banehager - utbredelse og holdninger blant personalet", diskuterer Knut Steinar Engelsen m.fl. computerspil i børnehaven og pædagogernes holdning til dem. Kapitlets diskussion bygger på en kvalitativ undersøgelse, der fandt sted fra 2008 - 2011. Undersøgelsen viser, at de professionelle generelt har et konstruktivt og kritisk blik på brugen af computerspil i børnehaven. De ser et læringspotentiale i computerspillene og mener samtidig, at det er vigtigt, at børnehaven spiller en rolle i forhold til at forberede børnene på den digitale hverdag, de vil møde senere hen i livet. Problemet med computerspillene er, som forfatterne påpeger, at pædagogens rolle ofte reduceres til kontrollant frem for en aktiv og deltagende aktør. Dette kapitel hænger således godt sammen med det foregående, hvor fokus er på, hvorledes de voksne kan indgå i nye former for deltagende handlingsrum. Forfatterne konkluderer, at der i relation til computerspillene kan opstå "et spenningsfelt mellom på den ene side barnas utforskertrang og på den andre siden førskolelærerens behov for regulering og styring af aktiviteten" (p. 123). Dermed illustrerer kapitlet på bedste vis, at medier har forskellige egenskaber, hvad angår brug og dermed også læring. I det syvende kapitel, "Veiledet samspill i barnehagen: undersøkelse av hvordan voksne kan støtte barns læring med digitale medier", diskuterer de to skotske forskere Christine Stephen og Lydia Plowman med afsæt i projektet "Interplay" fireåriges læring med teknologi i børnehaven og argumenterer for vigtigheden af vejledt samspil, for at små børn får gode oplevelser med teknologien. Familien spiller en rolle, hvad angår børns erfaring 
med teknologi og medier: "Ulike erfaringerne i hjemmet betyr at barn på ethvert lekerom vil ha ulike muligheter for og forventninger til hvordan de skal engasjere seg i læring med teknologi: Målrettet veiledet samspill er avgørende hvis de skal ha produktive møter med digitale medier i barnhagen" (p. 143). I det ottende kapitel, "Barndommens medialisering og de voksne", diskuterer Henriette Jæger med afsæt i et projekt om den digitale fortælling, hvorledes og med hvilken effekt børns medieerfaringer kan gøres til genstand for refleksion. Den voksnes rolle er at hjælpe børnene med at bearbejde, sortere og reflektere over de indtryk, de får igennem medierne. Det kræver mediekompetente voksne, for samspillet med den voksne har afgørende betydning for, hvordan fortællingerne udformes og derved også for om refleksion og nye erfaringer skabes. I det sidste og niende kapitel, "Mama - hvorfor er TV så kjedelig - internett i barnehagen: om muligheter, risiko, moralsk panikk og digital lek", diskuterer Elisabeth Staksrud risici på internettet og sammenhængen mellem risiko, skade og udvikling hos små børn. Der gives konkrete råd til, hvad børnehaven kan gøre. Særligt effektivt er aktiv mediering, hvor den voksne sidder sammen med børnene, når de bruger internettet og taler med dem om det, de oplever. Forfatteren konkluderer - som flere af de andre kapitler også gør: "Den trygge voksen-relasjonen er - som alt annet - viktigst av alt" (p. 167).

Bogen har samlet set både gode og vigtige diskussioner af børns medieopvækst og -barndom og børnehaven som en digital dannelsesarena. Også i relation til en dansk børnehavekontekst i og med, at Norge og Danmark begge tilhører samme nordiske tradition, der anser det som en pædagogisk opgave for daginstitutionerne at understøtte børnenes egne læringsstrategier og det enkelte barns udviklingspotentiale. I Danmark er man i fuld gang med at digitalisere de offentlige institutioner, herunder skoler og daginstitutioner, og finde måder, hvorpå man kan udnytte de digitale medier med henblik på både at effektivisere og modernisere den offentlige service og uddannelse. Til dette arbejde er inspiration og gode erfaringer vigtigt. Denne bog videregiver mange gode erfaringer og stiller relevante og kritiske spørgsmål til de digitale mediers dannelsespotentiale og kan derfor inspirere især pædagoger og pædagogstuderende, der interesserer sig for eller direkte arbejder med at skabe nye digitale lærings- og legedesign i børnehaven.

Lotte Nyboe

Lektor, ph.d. Institut for Kulturvidenskaber Syddansk Universitet I.nyboe@sdu.dk 